\title{
Merkel Cell Development in the Wound Healing in the Labial Mucosa of Adult Rabbits*
}

\author{
Tamiko Tachibana and Kiyoto Ishizeki \\ Department of Oral Anatomy (Prof. T. NAwA), Iwate Medical University School of Dentistry, \\ Morioka, Japan
}

Received July 29, 1980

Summary. Merkel cell development was studied in the regenerative labial mucous membrane of adult rabbits. Fullthick wounds were made on the inferior labial mucous membrane of the rabbits, then the regenerative mucous membrane was examined by electron and light microscopy at time intervals of $2,7,10,14,21$ and 30 days after the injury. By 7 days, the regenerative area of the mucous membrane was replaced with a dense lamellar connective tissue, which was mainly composed of alternately arranged collagen fiber layers and fibroblasts, and an overlying stratified squamous epithelium. No Merkel cell was found 7 days after the injury. Ten days after the injury, a few very immature Merkel cells were identified in the regenerative epithelium. The Merkel cells increased in number and matured in structure during the course of the following regenerative period. Thirty days after the injury, the wounded area healed without forming a scar tissue, and the regenerated epithelial ridges usually included regular type Merkel cells. As adult animals were used in this experiment, the reproduction of the Merkel cell in the regenerative epithelium seemed to be independent of the undifferentiated neuroectodermal tissue.

The Merkel cell is the unique receptor-like cell which is located in the epithelial layer of the skin and in the oral mucous membrane of various vertebrates. A lot of papers on the Merkel cell have appeared during the last two decades (CAunnA, 1962; Munger, 1965, 1977; Mustakallio and Kisstala, 1967; Smith, 1967, 1970; Iggo and Muir, 1969; Kurosumi et al., 1969; Breathnach, 1971; Lyne and Hollis 1971; Hashimoto, $1972 \mathrm{a}$, b; Andres and During, 1973; Nafstad, 1971a, b; Winkelmann and Breathnach, 1973; English, 1974, 1977; Wheitear, 1974; Budtz and Larsen, 1975; Halata, 1975; Saxod, 1978; Tweedle, 1978; Tachibana, 1978, 1979, and many others). But the life history, including the developmental origin, of the Merkel cell is not necessarily clear.

Several investigators have contributed to this field by developmental and experimental approaches (BREATHNACH, 1971; Lyne and Hollis, 1971; Hashimoto, 1972a; English, 1974; Tachibana, 1979; Tachibana and Nawa, 1980; Tachibana. Sakakura

* A part of this research was supported by scientific research fund from the Ministry of Education of Japan. 
and Nawa, 1980). Though Breathnach (1971) and Hashimoto (1972a) found the existence of the Merkel cell in the primitive dermis of human fetal skin and suggested that the epidermal Merkel cell might be derived from the neuro-ectodermal (or the neural crest) cell, no further evidence supporting this has been proposed until now. Contrary to this, recent studies have strongly suggested a close relationship between the Merkel cell and the keratinocyte (ENGLish, 1974, 1977; SAxod, 1978; Tachibana and Nawa, 1980). Tachibana and Nawa (1980) showed that the Merkel cell of the labial mucous membrane of the rabbit developed in the epithelial layer via a cell which showed a transitional structure between the Merkel cell and the keratinocyte during the course of postnatal development of the rabbit. Certain workers have suggested that the neuro-ectodermal cells may be irrelevant to the development of the Merkel cell in the larval amphibian skin (TweEdLE, 1978; Tachibana, 1979; Tachibana et al., 1980). The same thing may be expected in mammals too.

In order to obtain a more convincing evidence, however, it seems important to prove that the Merkel cell in mammals can develop either in the skin or in the oral mucous membrane from which the neuro-ectodermal elements are excluded. The present experimental study was carried out from this point of view.

This paper will report on the appearance and the morphological changes of the Merkel cell in the regenerative epithelium of the labial mucous membrane of the adult rabbit after being wounded by a full-thick excision.

\section{MATERIALS AND METHODS}

Fourteen adult rabbits whose ages ranged from 6 to more than 12 months were used irrespective of their sex. A tissue piece, about $2 \times 2 \mathrm{~mm}$ squar and $1.5 \mathrm{~mm}$ thick was excised from the inferior left-hand labial mucosa of each animal under Nembutar anesthesia. By examination with the light microscope, it was ascertained that the excision reached the muscle layer. The animals were kept without any special treatment of the wound. They were divided into six groups to be submitted to the study of the regenerative tissue $2,7,10,14,21$ and 30 days after the injury. The regenerating mucous membrane was distinguishable from the intact tissue by its pale color at least by 21 days after the injury.

The animals of each group were perfused with $2.5 \%$ glutaraldehyde buffered in cacodylate $(\mathrm{pH} \mathrm{7.2)}$ under Nembutar anesthesia. Then the healing wound mucosa, including the peripheral intact region, and the normal mucosa of the opposite side were excised, and were immersed in the same fixative for $2 \mathrm{hrs}$. Following fixation with $1 \% \mathrm{OsO}_{4}$, the specimens were embedded in Epon 812 by the usual method.

The regenerative areas in the specimens were confirmed again with semithin sections under the light microscope, and trimmed if necessary. Every experimental specimen was totally sectioned, ultrathin sections being mingled with semithin sections. The controle specimens obtained from the right-hand labium were also cut partly with ultrathin sections and partly with semithin sections. The ultrathin sections were mounted on the formvar coverd single slot grids $(\varphi=2 \times 1 \mathrm{~mm})$ and observed with the light microscope after being stained with uranyl acetate and lead citrate. The semithin sections were observed with the light microscope after toluidine blue staining. 
The types of Merkel cells appearing in the regenerative mucosa were analysed and compared at the different healing stages in the following manner. A series of ultrathin sections was cut at $20 \mu \mathrm{m}$ intervals from each experimental specimen. The Merkel cells were classified into three different types (see Results). The total number of each cell type in each section series was calculated and the histograms were drawn.

\section{RESULTS}

\section{Classification of Merkel cell}

As was shown in the previous paper (TACHibana and NAwA, 1980), various types of the Merkel cell can be seen in the labial mucous epithelium of the postnatal developing rabbit. Though the cell type changes sequentially according as the cell differentiates, we would like to classify the Merkel cell into three types.

Type I (Fig. 1): Type I cell is characterized by smooth cell surface and electron lucent cytoplasm when compared with the other types of the Merkel cell. The cell is also characterized by the electron-dense bundles of cytofilaments which are located densely in the perinuclear region of the cytoplasm. A few membranebounded, oval dense bodies measuring about 2,000-2,800 A in their long diameter are usually present in the cytoplasm. The dense cored vesicles, about $1,000 \AA$ in diameter, which are characteristic of the mature Merkel cell, are scanty. The nucleus is large and usually contains a small inclusion consisting of fine filaments.
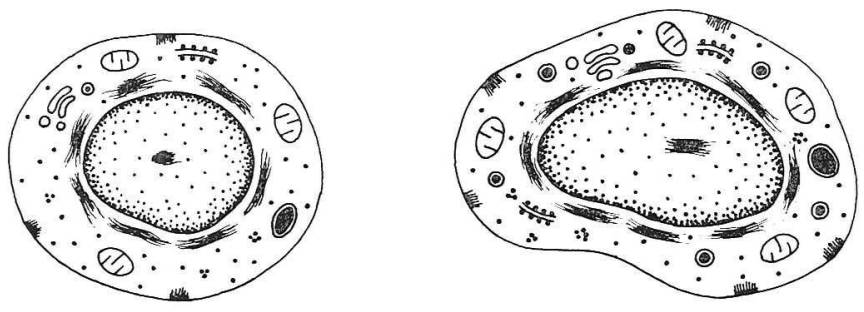

TYPE I

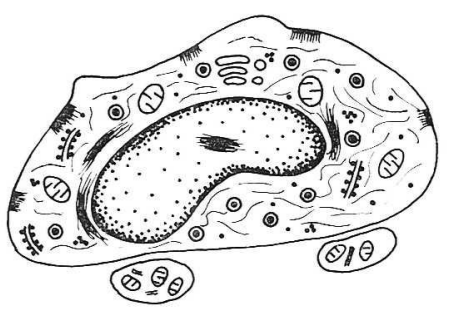

TYPE II

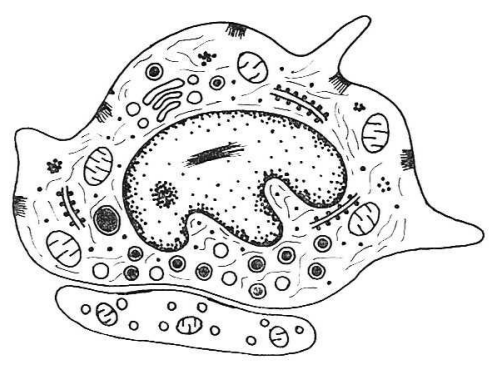

TYPE III

Fig. 1. Schema showing the classification of the Merkel cell types. Merkel cell matures gradually from type I to type III. 
This type cell is an immature Merkel cell and does not connect with the nerve fiber.

Type II (Fig. 1): This cell type is characterized by a rather enlarged and irregular cell body when compared with type I. The cell involves an irregular nucleus with a fibrous inclusion, an increased number of electron-dense cored vesicles and a greatly decreased number of electron-dense fibrilar bundles. In place of fibrilar bundles, numerous isolated cytofilaments are dispursed throughout the cytoplasm. There is no particular localization within the cytoplasm of the dense cored vesicles. The cell is connected to the nerve fiber in places, but the typical synaptic structure is not yet developed.

Type III (Fig. 1): This type shows the typical structural features of the mature Merkel cell which is generally known. The cell is characterized by an oval cell body with a specific finger-shaped cytoplasmic projection, an irregular shaped nucleus containing a nuclear inclusion, electron-dense cored vesicles accumulated in the cytoplasm facing the nerve ending and synaptic contact with the nerve ending. The electron-dense fibrilar bundle is seldom found in this type of Merkel cell.

\section{General structure of the normal labial mucosa}

The labial mucous membrane of the adult rabbit consists of a para-keratinized stratified squamous epithelium and a lamina propria which is composed of fibrous connective tissue. The epithelial-connective tissue junction shows an irregular appearance due to the interdigitation of the epithelial ridges and the papillae of connective tissue (Fig. 2). Type III Merkel cells are usually located in the basal layer of the epithelial ridges, frequently in clusters (Fig. 2, 3). Type I and type II cells are rarely found in the normal labial mucosa.

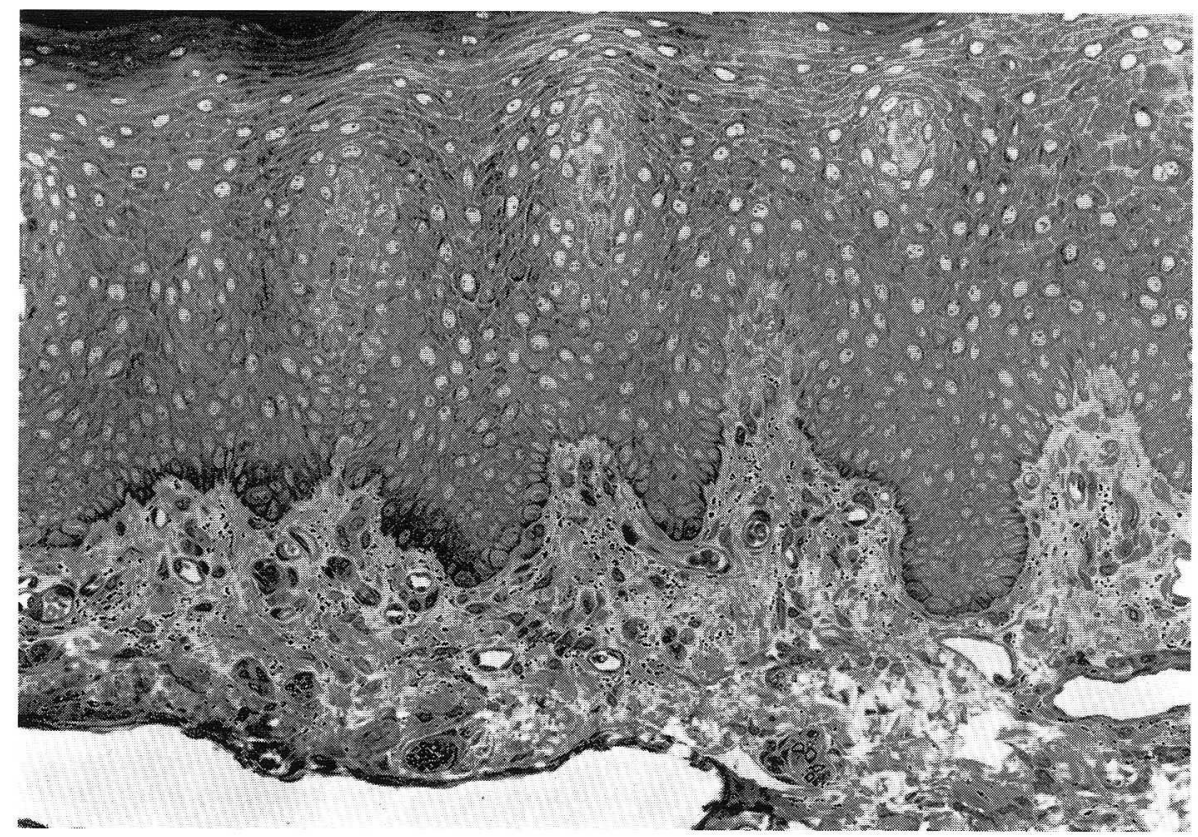

Fig. 2. Light micrograph of the normal labial mucosa of the adult rabbit. The epithelial ridges include many Merkel cells. $\times 400$ 
The connective tissue is somewhat looser in the papillary layer than in the deeper layer, and is supplied with an abundance of blood capillaries and nerve fibers. Meissner's corpuscles are frequently found in the papillae. Salivary glands are never found in the connective tissue layer.

\section{Appearance and differentiation of Merkel cell in the regenerative labial mucosa}

Two days after wounding, the excised area of the mucous membrane was covered with a blood clot. Under the blood clot, the migration of the flat epithelial cells was starting from the wound edges. The accumulation of free cells such as leucocytes, macrophages and plasma cells were observed in the underlayer of the blood clot and the regenerative epithelium.

By 7 days after the injury, the excised area of the mucosa was replaced with the characteristic dense connective tissue and the overlying stratified squamous epithelium (Fig. 4). The connective tissue was packed with flat fibroblasts, free cells and intervening collagen fiber layers, which were arranged in a lamellic pattern (Fig. 4). Newly formed fine blood capillaries were recognized in the regenerative connective tissue, but no nerve fiber was identified.

The boundary between the epithelium and connective tissue in the regenerative mucosa was fairly straight, and no epithelial ridge was identified (Fig. 4). Various kinds of leucocytes existed in the basal epithelial layer, but no Merkel cell was found.

By 10 days, a few irregular epithelial projections protruded into the connective

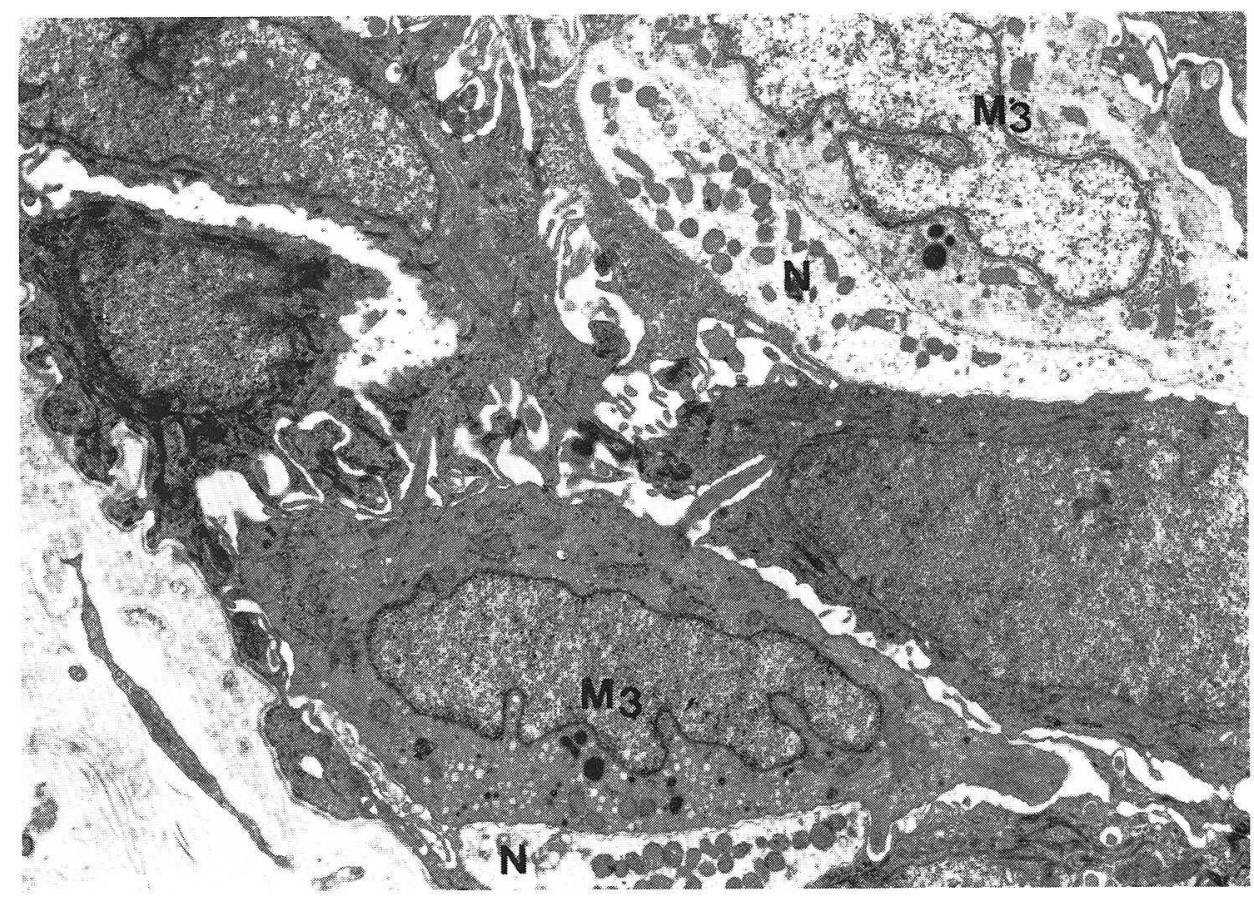

Fig. 3. Type III Merkel cells $\left(M_{3}\right)$ in the epithelial ridge of normal labial mucous membrane of the adult rabbit. Both Merkel cells differ from each other in the electron density of their cytoplasm. $N$ nerve endings. $\times 6,500$ 


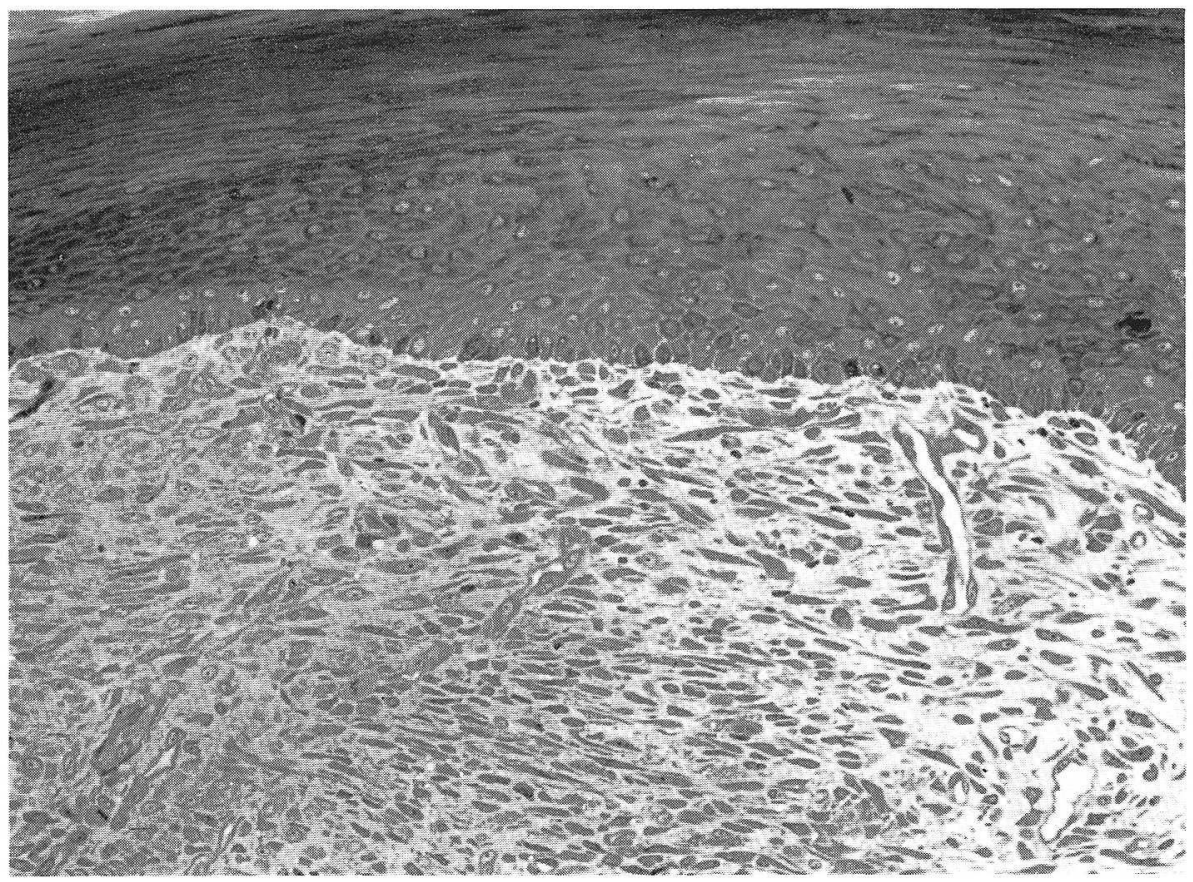

Fig. 4. Light micrograph of the regenerative labial mucous membrane of the rabbit 7 days after the injury. The epithelial-connective tissue boundary is almost straight. The connective tissue shows characteristic lamellate arrangement of flat fibroblasts. $\times 400$

tissue layer (Fig. 5). The connective tissue kept its characteristic lamellate appearance, though blood capillaries had increased in number. Sometimes fine unmyelinat ed nerve fibers with Schwann cells, which vertically penetrated the regenerative connective tissue, were found near the edge of the wound (Fig. 6). Observation of serial ultrathin sections confirmed that the nerve terminals penetrated into the epithelial layer (Fig. 6). Specific cells which had a smoother surface than the neighboring immature keratinocytes were distinguished in the basal epithelial layer (Fig. 7). The cell involved electron-dense bundles of cytofilaments located around the nucleus (Fig. 7). Existence of the small nuclear inclusion and of the large dense bodies in these cells was confirmed with the serial ultrathin sections. In one cell, an immature cored vesicle was identified near the Golgi apparatus. From the above observations, the cells in question seemed to be the very immature type I Merkel cells. No other type of Merkel cell was identified at this regenerative stage.

Fourteen days after wounding, the boundary between the epithelium and connective tissue became more irregular than 10 days due to the expansion of the epithelial ridges. The connective tissue lying between the epithelial ridges was looser than the remaining connective tissue, and it usually included blood capillaries and fine unmyelinated nerve fibers with a Schwann's sheath. The remainder of the connective tissue had the same characteristic lamellate arrangement of fibroblasts and intervening collagen fiber layer, though an increased supply of blood vessels and nerve fibers were noted in this layer. 


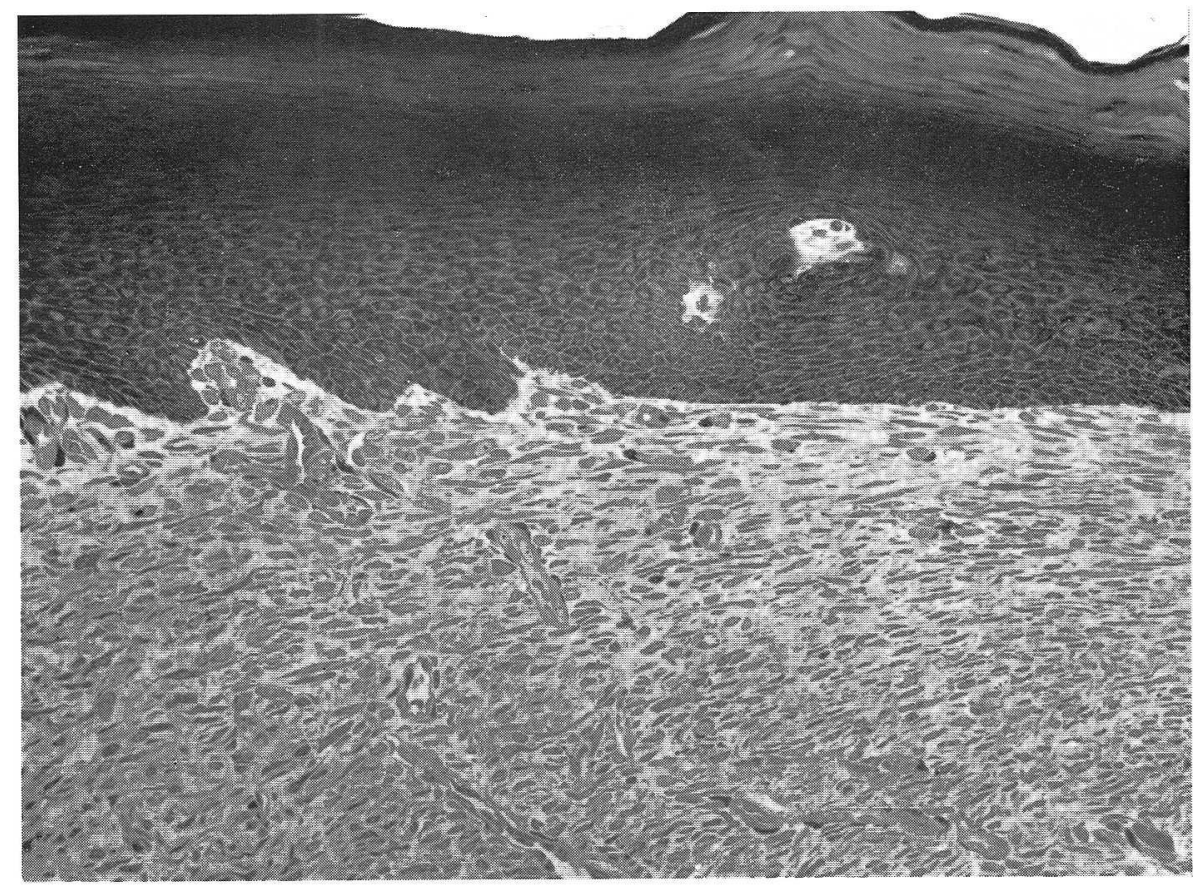

Fig. 5. Light micrograph of the regenerative labial mucous membrane 10 days after the injury. Regeneration of the epithelial ridges has begun. The connective tissue lying between the epithelial ridges is looser than that lying beneath the straight area of the epithelium. $\times 430$

Three types of Merkel cells were identified in the regenerated epithelium, not only in the epithelial ridges but also in the concave or straight areas between the ridges (Fig. 8, 9). The most frequent cell type was type II (Fig. 12). Forty-four Merkel cells were identified in 12 sections, which were cut at $20 \mu \mathrm{m}$ intervals and include $1,400 \mu \mathrm{m}$ of epithelium respectively. A rough estimation shows that an average of 2.6 Merkel cells were distributed in $1,000 \mu \mathrm{m}$ of the epithelium.

Serial sections revealed that most of the type II Merkel cells were connected to nerve fibers, though typical synaptic structures had not developed.

By 21 days after the injury, the connective tissue in the regenerative mucous membrane changed to a rather irregular appearance due to an increase in the number of blood vessels and nerve fiber bundles, though the particular lamellate pattern of fibroblasts and collagen fibers persisted in some places (Fig. 10). In the regenerative connective tissue layer, many bundles of myelinated nerve fibers were recognized in the deeper portions (Fig. 10). The nerve terminals which were enclosed by lamellate connective tissue cells were also observed in the connective tissue.

An increased number of Merkel cells was found in the regenerative epithelium. Type III Merkel cell was the most frequent (Fig. 11, 12). Thirty-seven Merkel cells were identified 10 sections, each section containing $850 \mu \mathrm{m}$ of regenerative epithelium. A rough estimation shows that approximately 4.4 Merkel cells were present in $1,000 \mu \mathrm{m}$ of the epithelium.

Thirty days after the injury, the regenerated mucosa became indistinctive in 


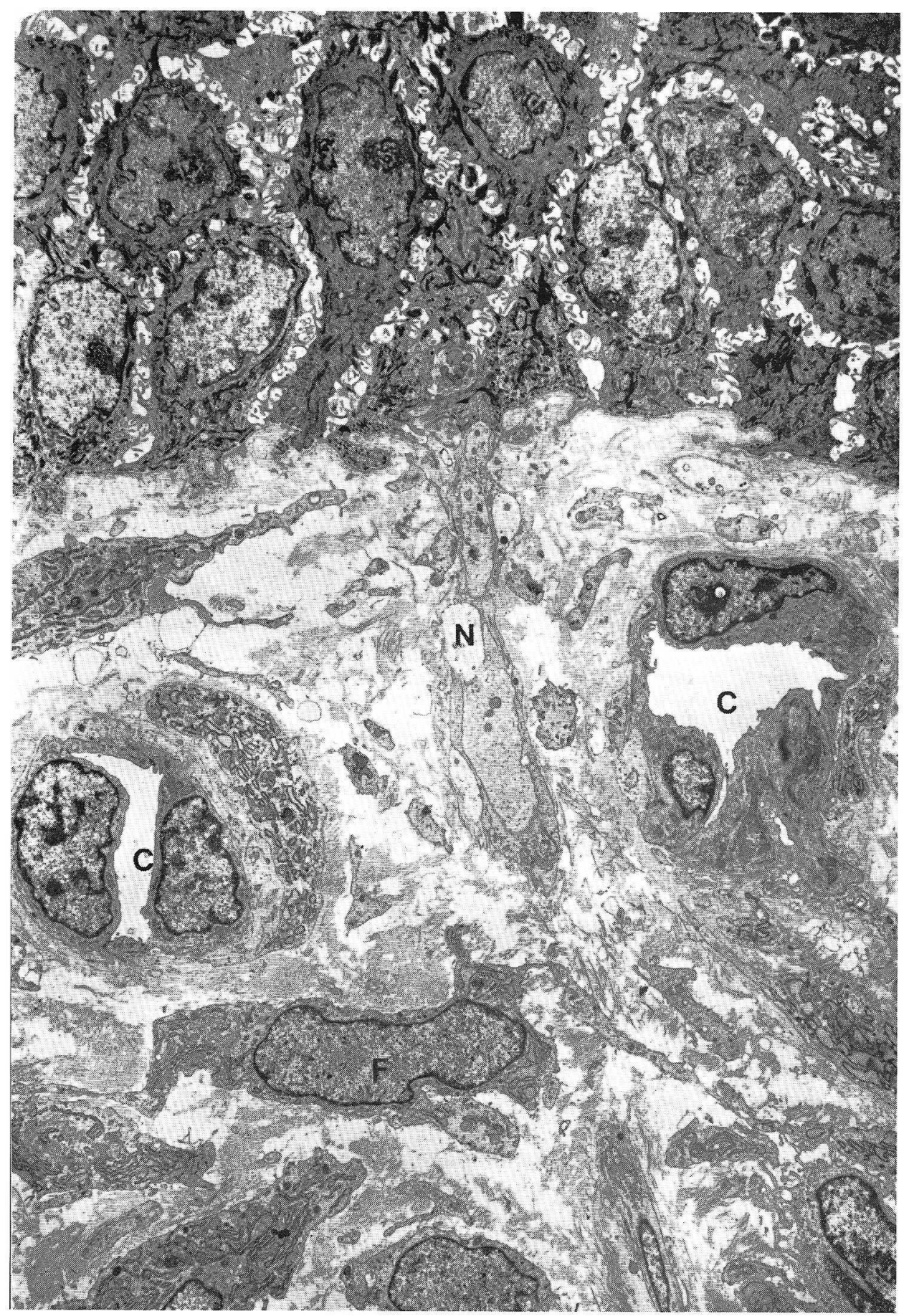

Fig. 6. The epithelial-connective tissue boundary of the regenerative labial mucosa 10 days after the injury. Fine nerve fiber $(N)$ which penetrates to the epithelial laver is seen here. $C$ capillaries, $F$ fibroblast. $\quad \times 3,700$ 


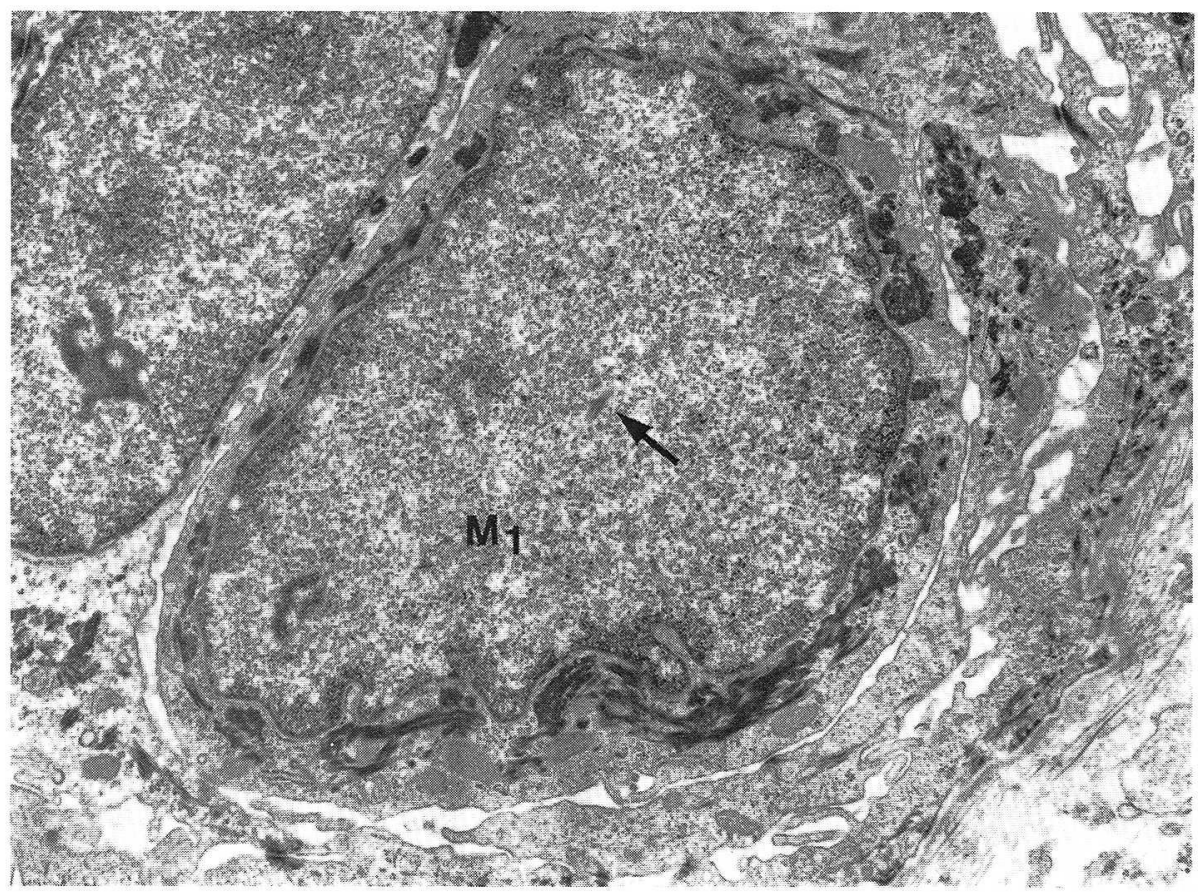

Fig. 7. Type I Merkel cell $\left(M_{1}\right)$ which was found in the regenerative epithelium 10 days after the injury. A small nuclear inclusion (arrow) can be seen. $\times 9,600$

appearence except for the grooves which developed at the edge of the wound. The mucous membrane almost regained its normal histological appearnce except that the regenerated epithelial ridges were relatively thinner than those of the intact mucosa (Fig. 13). The epithelial ridges usually involved type III Merkel cells in clusters.

\section{DISCUSSIONS}

Breathnach (1971) and Hashimoto (1972a) found Merkel cells in the primitive dermis of human fetal skin, and deduced that the epidermal Merkel cell was derived from the dermal Merkel cell. They suggested that a neuro-ectodermal (or the neural crest) cell might be the progenitor of the Merkel cell. On the other hand, Lyne and Hollis (1971), who studied the fetal skin of the sheep by electron microscopy, did not find any indication of the dermal Merkel cell and regarded the epidermal Merkel cell as a modified epidermal cell.

Recently, Tweedle (1978) reported that Merkel cells were found in the forelimb digit epidermis of aneurogenic Ambystoma maculatum larvae which previously had all the presumptive neural tissues, including the neural crest, removed. TAchibana (1979) and Tachibana et al. (1980) examined the developing anuran skin, with the labial ridges of Rana japonica and the tentacles of Xenopus laevis respectively, and showed that neither a Merkel cell nor a suspected neuro-ectodermal cell, was found in the mesenchymal layer. Therefore, it was suggested that the neuro-ectodermal 


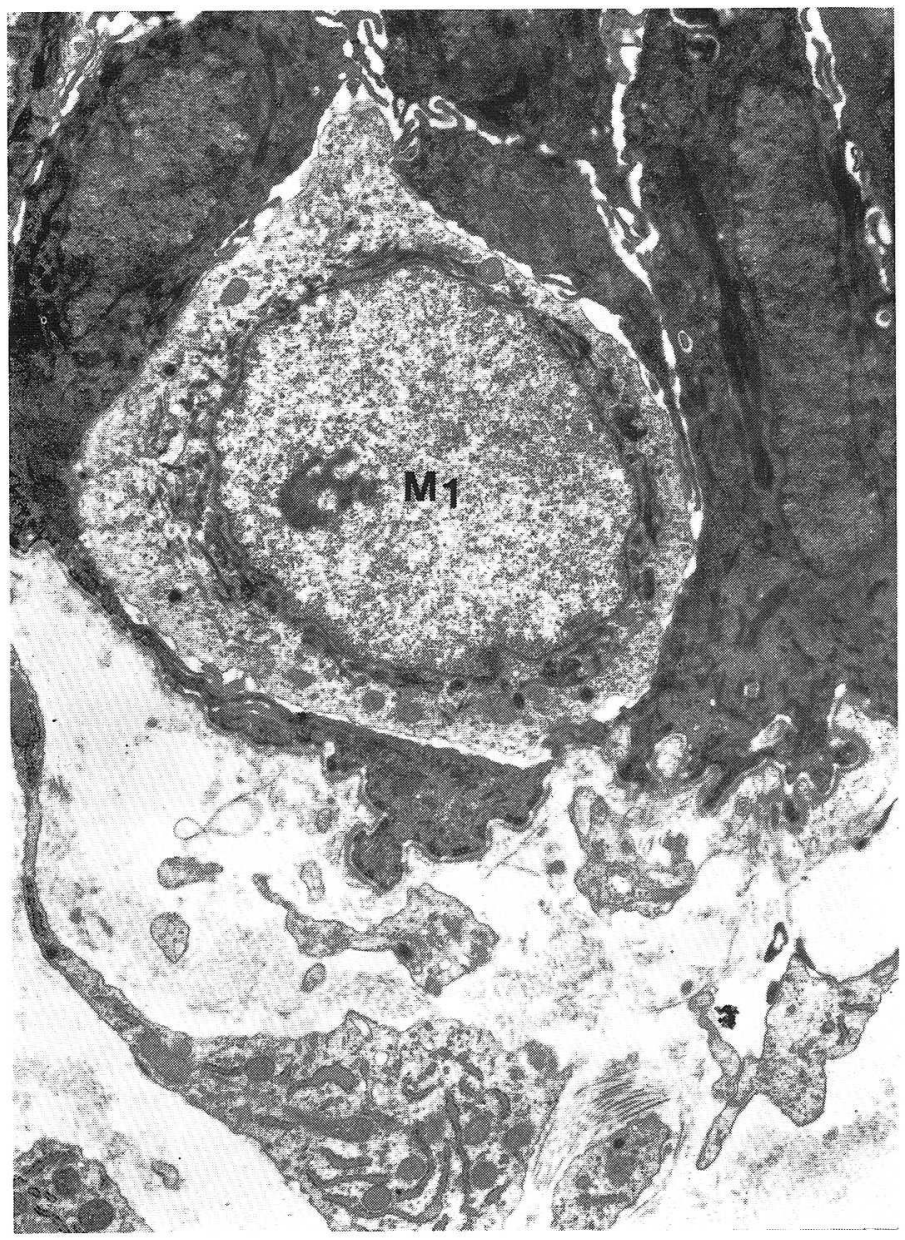

Fig. 8. Type I Merkel cell $\left(M_{1}\right)$ which was seen in the regenerative epithelium of the healing labial mucosa of the rabbit 14 days after the injury. $\times 6,500$

tissue might be irrelevant to the Merkel cell development, at least in amphibians.

Existence of specific cells in mammalian epidermis, which showed a transitional structure between the Merkel cell and the keratinocyte, has been pointed out by certain research workers (IGGo and Muir, 1969; NAFSTAD, 1971a, b; ENGLish, 1974, 1977; Saxod, 1978; TAchibana and NAWA, 1980). TAChibana and Nawa (1980) demonstrated that the transitional cell is simply a developing Merkel cell.

In the present study, it was shown that the regenerative epithelium of labial mucosa could produce the Merkel cell. It is well known that the oral mucous membrane has an unusual regenerative possibility and heal well without a suture. It is true that the labial mucous membrane that had been wounded by a full-thick excision regenerated differently than the skin. In the skin, it is known that the

Fig. 10. Light micrograph of the regenerative labial mucosa of the adult rabbit 21 days after the injury. The epithelial-connective tissue boundary became more irregular during regeneration of the epithelial ridges. The connective tissue also became more irregular due to the penetration of nerve fiber bundles and blood vessels. The transverse image of the bundles of myelinated nerve fibers can be seen in some places (arrows). $\quad \times 430$ 


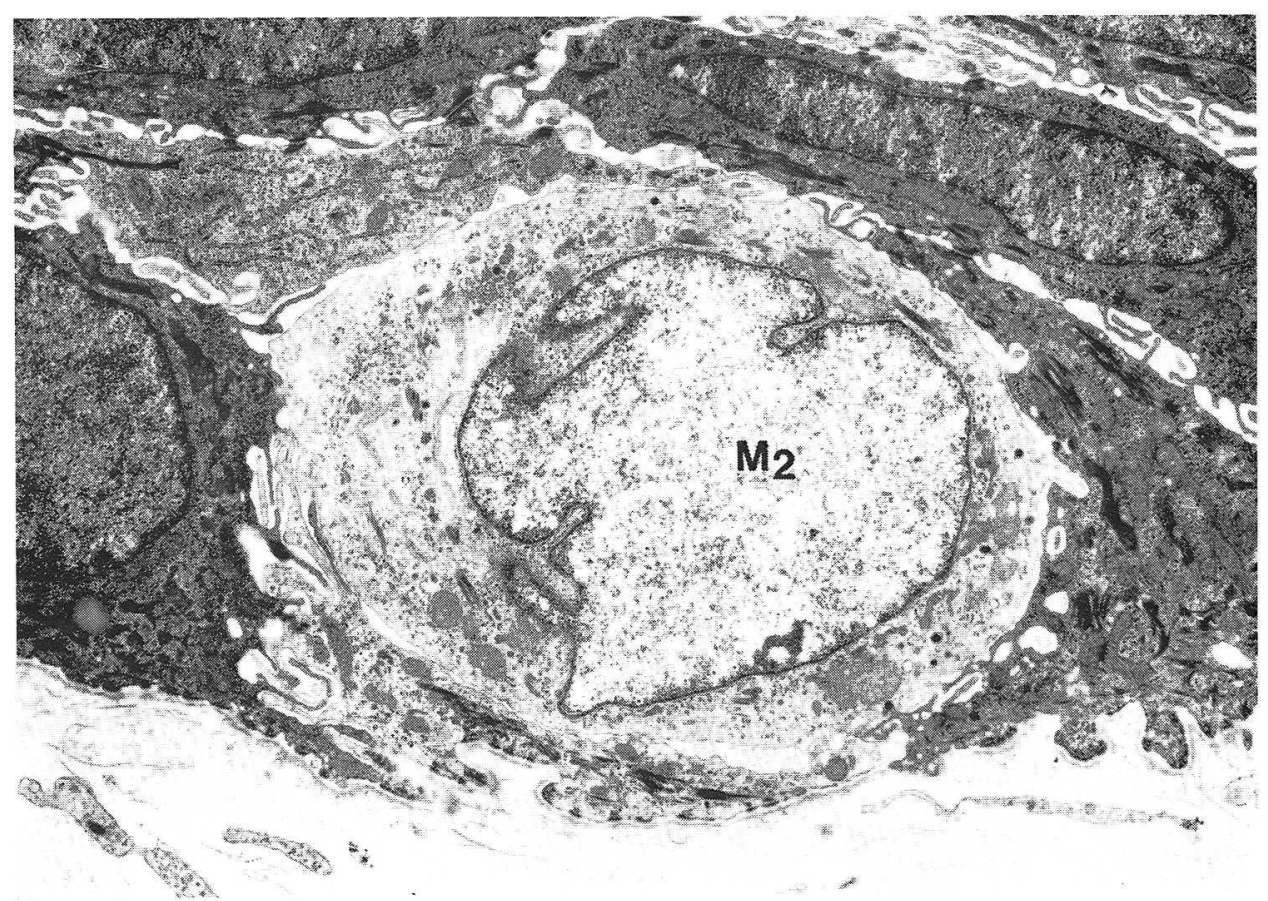

Fig. 9. Type II Merkel cell $\left(M_{2}\right)$ found in the regenerative epithelium 14 days after the injury. Note the fibrilar bundles remaining around the nucleus. $\times 7,500$

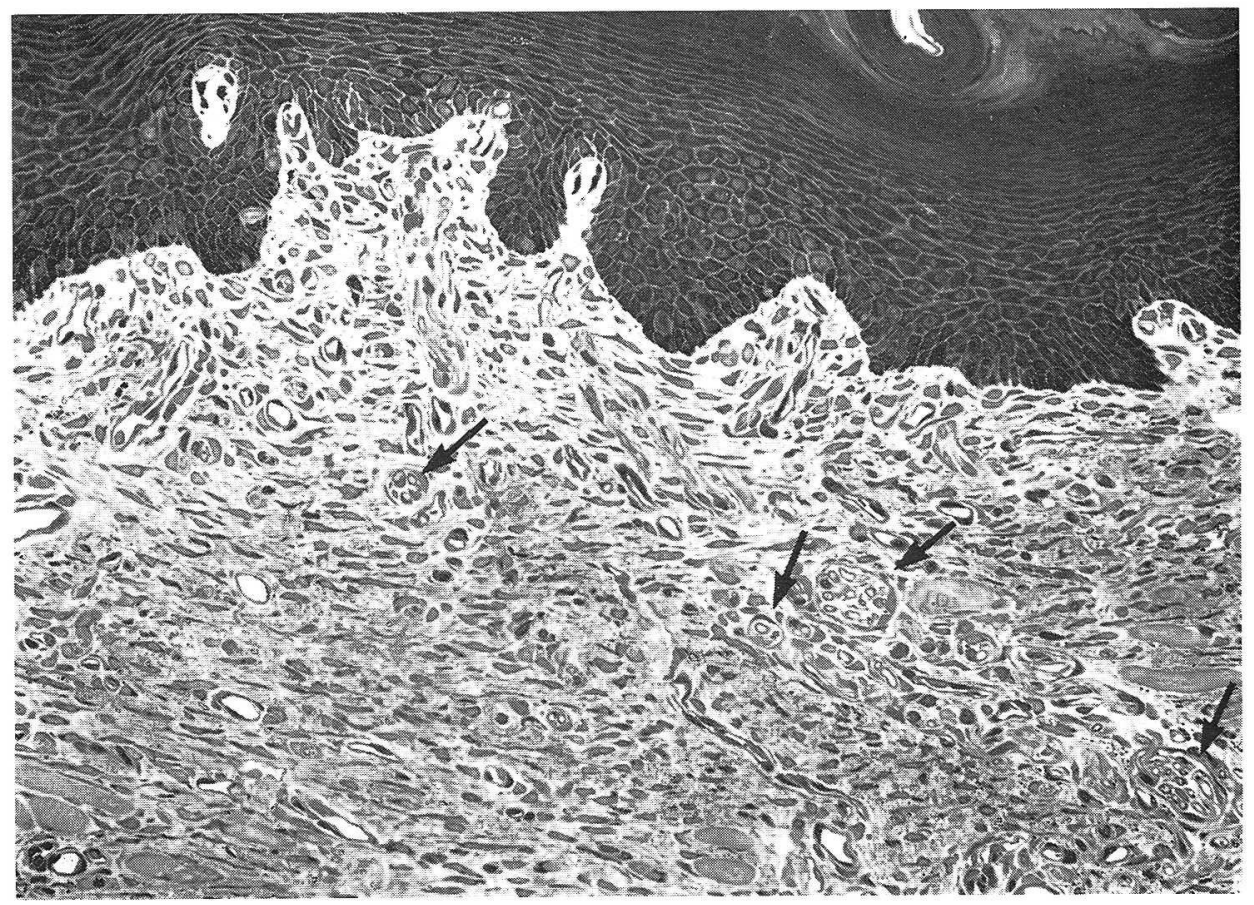

Fig. 10. Legend on the opposite page. 


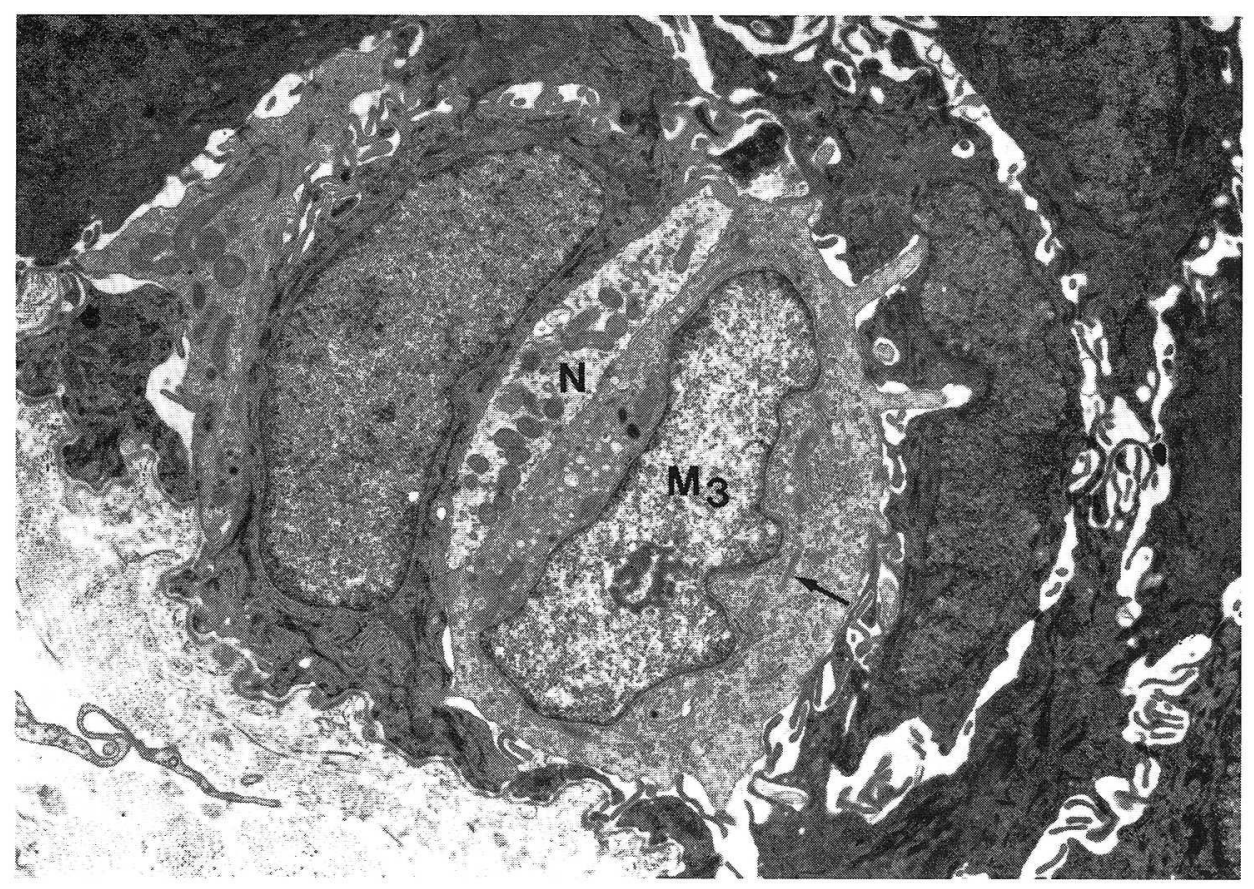

Fig. 11. Type III Merkel cell $\left(M_{3}\right)$ which was found in the regenerative labial mucosa of adult rabbit 21 days after the injury. A fibrilar bundles with a high electron density remained in the cytoplasm (arrow). Note the contact between the Merkel cell and a large nerve ending. $(N) \times 6,500$

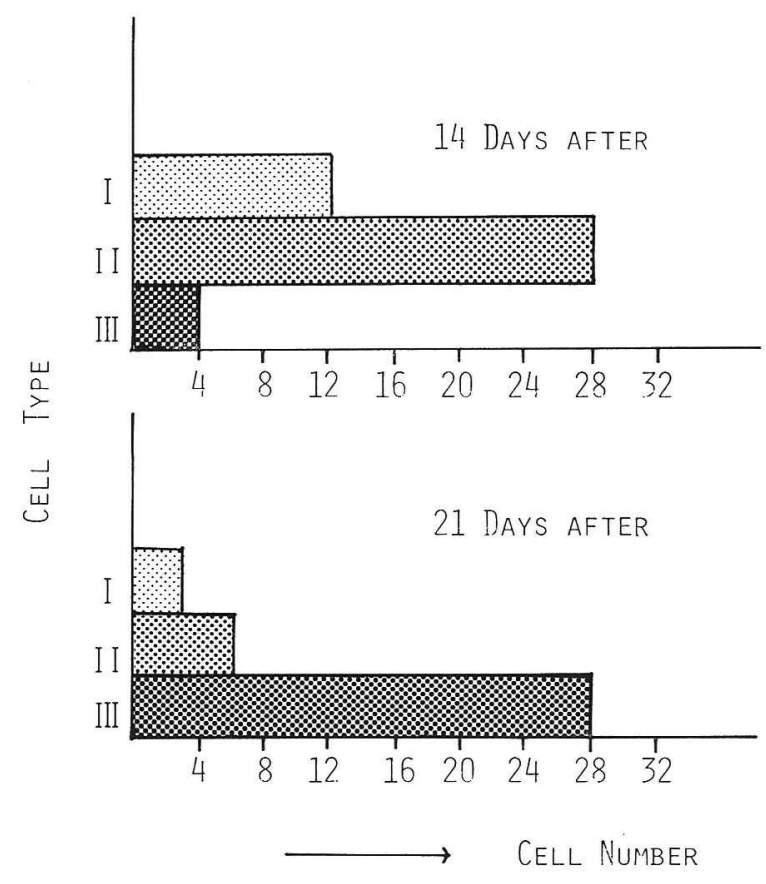

Fig. 12. Histograms showing the frequency of the different types of Merkel cells in the different regenerative stages. Twelve sections each of which contained $1,400 \mu \mathrm{m}$ of epithelium were analysed 14 days after the injury. Ten sections, each containing $850 \mu \mathrm{m}$ of epithelium, were analysed 21 days after the injury. 


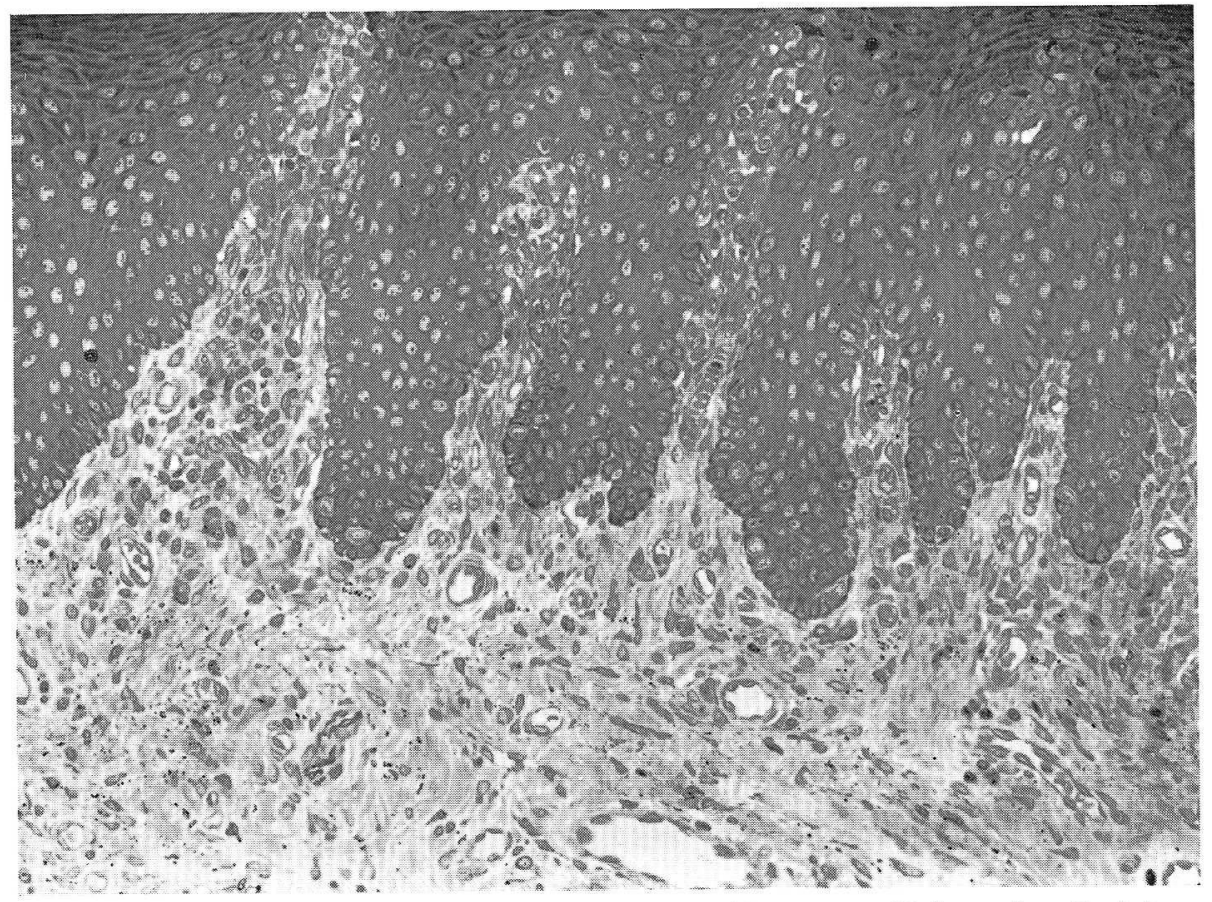

Fig. 13. Light microgram showing the regenerated labial mucosa 30 days after the injury. The histological appearance of the regenerated mucosa is comparable to the normal mucosa. The regenerated epithelial ridges include many Merkel cells. $\times 400$

scar tissue usually remaines in the regenerated area after a full-thick excision (PEACOCK and Wincle, 1970). The labial mucous membrane in the present study regained its normal histological appearance by 30 days after the injury without leaving a scar tissue. Though the oral mucosa thus possesses some peculiar physiological ability, it may be considered that this does not have a direct effect upon the interpretation of the results obtained by the present study.

The Merkel cell which appeared at the early regenerative stage was structurally quite immature and small in number. During the progression of the healing process, the Merkel cell increased in number and matured in structure. Moreover, in the earlier regenerative stages the Merkel cell had not developed in the epithelium. On the other hand, the normal labial mucosa rarely included an immature Merkel cell such as type I and type II. The same finding has previously been shown by Tachibana and Nawa (1980). Therefore, it is difficult to consider that the immature Merkel cells which appear in the regenerative epithelium might be provided by the intact epithelium area around the wound edge.

Because adult animals were used for the present experiment, neuro-ectodermal factors, except for Schwann cells, can be excluded from being candidates for the progenitor of the Merkel cell. In the present case, the authors noticed that the penetration of nerve fibers into the epithelium and the first appearance of type I Merkel cells occurred almost simultaneously. This may suggest a possibility that the Merkel cells originate from Schwann cells that have migrated from the connec- 
tive tissue layer. However, it was difficult to find Schwann cells in the epithelial layer in the present study. Also, the immature Merkel cell was not necessarily in contact with nerve fibers. Furthermore, there is no similarity in the cell structure between the Schwann cell and the Merkel cell. On the other hand, the immature Merkel cells show a similarity to the immature keratinocytes in the germinal epithelial layer, possessing desmosomes and tonofilament-like fibrilar bundles.

The evidence described above strongly supports the view that the Merkel cell originates from the germinal epithelial cell, probably from the immature keratinocyte.

\section{創傷治療過程の成熟ウサギロ唇粘膜におけるメルケル細胞の分化について}

立花民子と石関清人

口唇粘膜を一部切除した 成熟ウサギを用い，再生された粘膜に 再びメルケル細胞が出現 する過程を光線顕微鏡および透過電子顕微鏡で観察した。

術後 7 日目の創傷部は再生された重層扁平上皮と結合組織でおおおれ，結合組織は線 維芽細胞と膠原線維層が層状配列する 特異な構築を示した。結合組織と上皮の境界は平 担で，上皮中にメルケル細胞は見出されなかった，術後 10 日になると，上皮と結合組織 の境界はところどころ不規則になり，上皮稜の再生が始まったことを示した。また 上皮 基底層に 少数の極めて未分化なメルケル細胞が見出された，その後 術後日数の経過とと もに，結合組織は血管や神経線維の再生によって不規則になり，一方上皮中のメルケル 細胞の出現頻度は増加した。メルケル細胞の形態的分化も経過日数に伴って進行するのが 認められた。術後30日目の再生粘膜は 正常粘膜と同様の形態を示し，上皮稜中には 多数 の分化したメルケル細胞が観察された。今回の実験では 成熟ウサギを用いたので，再生 粘膜に出現したメルケル細胞の起源として未分化な神経性外肧葉細胞を想定するのは 困 難であると考えた.

\section{REFERENCES}

Andres, K. H. and M. During: Morphology of cutaneous receptors. In: (ed. by) A. Iggo: Handbook of sensory physiology 2, Somatosensory system. Springer Verlag, Berlin-HeiderbergNew York, 1973, (p. 3-28).

Breathnach, A. S.: Embryology of human skin. A review of ultrastructural studies. J. invest. Dermatol. 57: 133-143 (1971).

Budtz, P. E. and L. O. Larsen: Structure of the toad epidermis during the moulting cycle. II. Electron microscopic observation on Bufo bufo (L). Cell Tiss. Res. 159: 459-483 (1975).

Cauna, N.: Functional significance of the submicroscopical, histochemical and microscopical organization of the cutaneous receptor organs. Anat. Anz. 111: 181-197 (1962). 
English, K. B.: Cell types in cutaneous type I mechanoreceptors (Haarscheiben) and their alterations with injury. Amer. J. Anat. 141: 105-126 (1974).

-: The ultrastructure of cutaneous type I mechanoreceptors (Haarscheiben) in cat following denervation. J. comp. Neurol. 172: 137-164 (1977).

Halata, Z.: The mechanoreceptors of the mammalian skin. Adv. Anat. Embryol. Cell Biol. 50: 7-75 (1975).

Hashimoto, K.: The ultrastructure of the skin of human embryos. X. Merkel tactile cells in the finger and nail. J. Anat. 111: 99-120 (1972a).

: Fine structure of Merkel cell in human oral mucosa. J. invest. Dermatol. 50: 381-387 (1972b).

Iggo, A. and A. R. Muir: The structure and function of a slowly adapting touch corpuscle in hairly skin. J. Physiol. (London) 200: 763-796 (1969).

Kurosumi, K., U. Kurosumi and H. Suzuki : Fine structures of Merkel cells and associated nerve fibers in the epidermis of certain mammalian species. Arch. histol. jap. 30: 295-313 (1969).

Lyne, A. G. and D. E. Hollis : Merkel cells in sheep epidermis during fetal development. J. Ultrastr. Res. 34: 464-472 (1971).

Munger, B. L.: The intraepidermal innervation of the snout skin of the opossum. J. Cell Biol. 26: 79-97 (1.965).

: Neural-epithelial interaction in sensory receptors. J. invest. Dermatol. 69: 27-40 (1977).

Mustakallio, K. K. and U. Kiistala : Electron microscopy of Merkel's “Tastzelle," a potential monoamine storing cell of human epidermis. Acta dermatovenerol. 47: 323-326 (1967).

Nafstad, P. H. J.: Comparative ultrastructural study on Merkel cells and dermal basal cells in poultry (Gallus domesticus). Z. Zellforsch. 116: 342-348 (1971a).

-: On the ultrastructure of neuro-epithelial interactions. The dermal innervation in the snout of the pig. Z. Zellforsch. 122: 528-537 (1971b).

Peacock, E. E. and W. V. Wincle: Surgery and biology of wound repair. W. O. Saunders Co., Philadelphia-London-Tronto, 1970.

Saxod, R.: Ultrastructure of Merkel corpuscles and so-called 'transitional' cells in the white leghorn chicken. Amer. J. Anat. 151: 453-474 (1978).

Smith, K. R. Jr : The structure and function of the Haarscheibe. J. comp. Neurol. 131:459-474 (1967). : The ultrastructure of the human Haarscheibe and Merkel cell. J. invest. Dermatol. 54: 150-159 (1970).

Tachibana, T.: The Merkel cell in the labial ridge epidermis of anuran tadpole. I. Fine structure, distribution and cytochemical studies. Anat. Rec. 191: 487-502 (1978).

- : The Merkel cell in the labial ridge epidermis of the anuran tadpole. II. Electron microscope observations on the appearance and differentiation of the Merkel cell. Arch. histol. jap. 42: 129-140 (1979).

Tachibana, T. and T. Nawa: Merkel cell differentiation in the labial mucous epithelium of the rabbit. J. Anat. 131: 145-155 (1980).

Tachibana, T., Y. Sakakura and T. Nawa: Merkel cell differentiation in the developing tentacles of Xenopus laevis. Acta anat. nippon. 55: 588-599 (1980).

Tweedle, C. D.: Ultrastructure of Merkel cell development in aneurogenic and controle amphibian larvae (Ambystoma). Neuroscience 3: 481-486 (1978).

Wheitear, M.: The nerves in frog skin. J. Zool. (London) 172: 503-529 (1974).

Winkelmann, R. and A. S. Breathnach : The Merkel cell. J. invest. Dermatol. 60: 2-15 (1973).

立花民子

干020 盛岡市中央通 1 丁日 3 の 27

岩手医科大学歯学部

第二口腔解剖学講座
Tamiko Tachibana

Department of Oral Anatomy

Iwate Medical University

School of Dentistry

Morioka, 020 Japan 